\title{
Analysis of Certain Nitrogenous Compounds in Tobacco. Part 1: Adenosine, 2,5- and 2,6-Deoxy- fructosazines, Mannosamine and Glucosamine*
}

\author{
by \\ Serban C. Moldoveanu, Crystal H. Byrd, and Anthony R. Gerardi \\ R. J. Reynolds Tobacco Co., Winston-Salem, NC 27105, USA
}

\section{SUMMARY}

Nitrogenous compounds such as amino acids and proteins are frequently analyzed in tobacco since they are considered precursors of toxicants in cigarette smoke. However, much less attention is given to other nitrogenous compounds such as amino sugars and deoxyfructosazines, although their concentration in tobacco can be equal to or even higher than that of most free amino acids. These nitrogenous compounds may contribute to the formation of toxicants in smoke, or may contribute to the sensory properties of cigarette smoke, reasons for which their analysis is important. This study describes a procedure for the analysis of adenosine, 2,5- and 2,6-deoxyfructosazines (DFs), mannosamine and glucosamine in tobacco. The analysis uses a liquid chromatography-tandem mass spectrometry (LC/MS/MS) technique. Sample preparation for analysis consists of the extraction of the tobacco with a solution of $90 \%$ water and $10 \%$ methanol, followed by filtration. The separation of the analytes was done on a hydrophilic interaction liquid chromatography HILIC column using an isocratic procedure with a solvent consisting of $78 \% \mathrm{CH}_{3} \mathrm{CN}, 22 \% \mathrm{H}_{2} \mathrm{O}$, that also contained $0.1 \% \mathrm{HCOOH}$ and $0.143 \mathrm{~g} / \mathrm{L} \mathrm{CH}_{3} \mathrm{COONH}_{4}$. The measurements were done using electrospray positive ionization mass spectrometric detection. The analytical procedure was validated and was proven very reliable. A number of tobaccos were analyzed, including several fluecured and Burley USA tobaccos, off-shore tobaccos, two Oriental tobaccos, two green tobaccos, as well as tobaccos from commercial and Kentucky reference cigarettes. The ranges for the analytes per $\mathrm{g}$ tobacco were found between 0.4 and $20.3 \mu \mathrm{g} / \mathrm{g}$ for adenosine, between 0.0 and $608.5 \mu \mathrm{g} / \mathrm{g}$ for 2,5-DF, between 0.0 and $424.5 \mu \mathrm{g} / \mathrm{g}$ for 2,6-DF, between 12.5 and $415.5 \mu \mathrm{g} / \mathrm{g}$ for mannosamine and between 25.9 and $1885.7 \mu \mathrm{g} / \mathrm{g}$ for glucosamine.

The study also indicated that the levels of DFs and that of the amino sugars in tobacco show a very good correlation.
This correlation can be explained by the same source of the two classes of compounds, namely the reaction of (reducing) sugars and ammonia. [Beitr. Tabakforsch. Int. 24 (2011) 233-242]

\section{KEYWORDS}

Adenosine, 2,5-and 2,6-deoxyfructosazines, mannosamine, glucosamine, tobacco, HPLC analysis, HILIC column

\section{ZUSAMMENFASSUNG}

Stickstoffhaltige Verbindungen im Tabak, wie Aminosäuren und Proteine, werden häufig untersucht, da sie als Vorläufer für toxische Substanzen im Zigarettenrauch betrachtet werden. Dagegen wird anderen stickstoffhaltigen Verbindungen wie Aminozuckern und Deoxyfructosazinen weniger Aufmerksamkeit gewidmet, obwohl deren Konzentration im Tabak genauso groß oder sogar größer ist, als die von freien Aminosäuren. Dass diese stickstoffhaltigen Verbindungen zu der Bildung von toxischen Substanzen im Tabakrauch oder zu den sensorischen Eigenschaften von Zigarettenrauch beitragen können, sind wichtige Gründe für die Untersuchung. Diese Arbeit beschreibt ein Verfahren zur Analyse von Adenosin, 2,5- und 2,6-Deoxyfructosazinen (DFs), Mannosamin und Glucosamin im Tabak. Zur Analyse wurde eine liquid chromatography-tandem mass spectrometry (LC/MS/MS)-Technik verwendet. Die Probenvorbereitung für die Analyse bestand aus der Extraktion des Tabaks mit einer Lösung aus 90\% Wasser und 10\% Methanol, gefolgt von einer Filtration. Die Analyten wurden mit Hilfe einer hydrophilic interaction liquid chromatography HILIC-Säule nach einem isokratischen Verfahren getrennt. Das Lösungsmittel bestand aus $78 \% \mathrm{CH}_{3} \mathrm{CN}, 22 \% \mathrm{H}_{2} \mathrm{O}$ mit $0.1 \% \mathrm{HCOOH}$ und $0.143 \mathrm{~g} / \mathrm{L} \mathrm{CH}_{3} \mathrm{COONH}_{4}$. Die Messungen

*Received: $2^{\text {nd }}$ August 2010 - accepted: $6^{\text {th }}$ March 2011 
wurden mit Hilfe einer Elektrospray-Positiv-Ionisierungsmassenspektrometrie detektiert. Das analytische Verfahren wurde validiert und hat sich als sehr zuverlässig erwiesen. Eine Vielzahl an Tabaken wurde untersucht, darunter einige Flue-cured und US-amerikanische Burley-Tabake, OffshoreTabake, zwei Orient-Tabake, zwei grüne Tabake, sowie Tabak von kommerziellen Zigaretten und Kentucky Referenzzigaretten. Die gemessenen Analyten pro g Tabak lagen für Adenosin in einem Bereich zwischen 0,4 und $20,3 \mu \mathrm{g} / \mathrm{g}$, für 2,5-DF zwischen 0,0 und $608,5 \mu \mathrm{g} / \mathrm{g}$, für 2,6DF zwischen 0,0 und $424,5 \mu \mathrm{g} / \mathrm{g}$, für Mannosamin zwischen 12,5 und 415,5 $\mu \mathrm{g} / \mathrm{g}$ und für Glucosamin zwischen 25,9 und $1885,7 \mu \mathrm{g} / \mathrm{g}$.

Die Untersuchung zeigt, dass der Gehalt von DFs und der Gehalt von Aminozuckern im Tabak sehr gut miteinander korrelieren. Diese Korrelation kann durch die gleiche Quelle dieser beiden Komponentenklassen, nämlich der Reaktion von (reduzierenden) Zuckern und Ammoniak, erklärt werden. [Beitr. Tabakforsch. Int. 24 (2011) 233-242]

\section{RESUME}

Les composés azotés tels que les aminoacides et les protéines sont fréquemment analysés dans le tabac car ils sont considérés comme des précurseurs des produits nocifs dans la fumée de cigarette. Beaucoup moins d'attention est toutefois portée à d'autres composés azotés tels que les sucres aminés et les déoxyfructosazines, bien que leur concentration dans le tabac puisse être aussi élevée, voire même supérieure à celle de la majorité des aminoacides libres. Ces composés azotés pourraient contribuer à la formation de produits nocifs dans la fumée, ou pourraient contribuer aux propriétés sensorielles de la fumée de cigarette. Leur analyse est donc importante. Cette étude décrit une procédure d'analyse de l'adénosine, des 2,5- et 2,6-deoxyfructosazines (DFs), de la mannosamine et de la glucosamine dans le tabac. Cette analyse utilise une technique liquid chromatography-tandem mass spectrometry (LC/MS/MS). La préparation des échantillons pour l'analyse consiste à extraire le tabac à l'aide d'une solution à $90 \%$ d'eau et $10 \%$ de méthanol, suivie d'une filtration. La séparation des analytes a été réalisée dans une colonne hydrophil interaction liquid chromatography HILIC en employant une méthode isocratique avec un solvant constitué à $78 \%$ de $\mathrm{CH}_{3} \mathrm{CN}$, à $22 \%$ de $\mathrm{H}_{2} \mathrm{O}$, il contenait

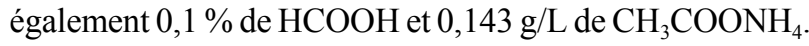
Les mesures ont été réalisées par électronébulisation ionique positive - spectrométrie de masse. La procédure analytique a été validée et elle s'est avérée très fiable. Plusieurs tabacs ont été analysés, y compris plusieurs tabacs séchés à l'air chaud et des tabacs burley américains, des tabacs off-shore, deux tabacs orientaux, deux tabacs verts ainsi que des tabacs de cigarettes commerciales et Kentucky de référence. Les fourchettes des analytes pro $\mathrm{g}$ tabac se situaient entre 0,4 et $20,3 \mu \mathrm{g} / \mathrm{g}$ pour l'adénosine, entre 0,0 et $608,5 \mu \mathrm{g} / \mathrm{g}$ pour 2,5 $\mathrm{DF}$, entre 0,0 et $424,5 \mu \mathrm{g} / \mathrm{g}$ pour $2,6-\mathrm{DF}$, entre 12,5 et 415.5 $\mu \mathrm{g} / \mathrm{g}$ pour la mannosamine et entre 25,9 et $1885,7 \mu \mathrm{g} / \mathrm{g}$ pour la glucosamine.

L'étude a également indiqué une très bonne corrélation entre les taux de DF et de sucres aminés dans le tabac. Cette corrélation peut s'expliquer par la source commune des deux classes de composés, à savoir la réaction des sucres réduits et l'ammoniaque. [Beitr. Tabakforsch. Int. 24 (2011) 233-242]

\section{INTRODUCTION}

Nitrogenous compounds such as amino acids and proteins are frequently analyzed in tobacco since they are considered precursors of toxicants in cigarette smoke, and higher response in the Ames tests have been correlated with higher level of nitrogenous compounds in tobacco (1-4). However, besides amino acids and proteins, much less attention is paid to other nitrogenous compounds such as amino sugars and deoxyfructosazines (DFs).

Their concentration can be equal or even higher than that of most free amino acids in tobacco (5). These compounds could be precursors of toxicants in smoke. Also, the sensory properties of cigarettes may be influenced by these compounds.

The chemical formulas of the compounds analyzed in this study are given in Figure 1. Adenosine is a nucleoside widely distributed in nature, and is also present in tobacco. The formation of DFs is mainly related to reactions between reducing sugars and $\mathrm{NH}_{3}$, both present in tobacco. Fructose (in open cycle form), for example, reacts with $\mathrm{NH}_{3}$ to form 2,5-DF as shown in Figure 2. Glucose also reacts with $\mathrm{NH}_{3}$ to form 2,6-DF as shown in Figure 3. Both reactions are associated with the formation of relatively high yields of browning polymers in which reactive molecules formed as intermediates between the sugar and $\mathrm{NH}_{3}$ condense to produce macromolecules (6). For this reason, the concentration of DFs in tobacco is likely to be correlated with the level of nitrogenous browning polymers. D-Glucosamine is the biochemical precursor of most nitrogen-containing sugars in biota and humans and is found naturally in the form of glucosamine-6-phosphate (7). Glucosamine-6-phosphate is synthesized from fructose6-phosphate and glutamine (8). Other sources of amino sugars are also possible.

The analysis of the above indicated nitrogenous compounds in various matrices and using various procedures has been reported in the literature. Adenosine, for example, was analyzed using high-performance liquid chromatography HPLC (9) or capillary electrophoresis (10). Analysis of deoxyfructosazines (DFs) was less frequently reported in the peer reviewed literature $(11,12)$. Descriptions of analytical procedures for glucosamine are more common because of the health-related implications of this compound. Glucosamine was analyzed by HPLC (13), by HPLC following some type of derivatization (14-19), by HPLC using refractive index detection (20), using LC/MS (21-24), by electrophoresis $(25,26)$, using highperformance thin-layer chromatography (27), or even by gas chromatography (28). Some of these methods allow the analysis of glucosamine and of mannosamine together (29-32).

The development of a unique method for the analysis of all five analytes with application to a tobacco matrix was the purpose of this study. Results for the analysis of these five analytes in tobacco were not previously published in peer reviewed literature. 
<smiles>Nc1ncnc2c1ncn2C1OC(CO)C(O)C1O</smiles>

adenosine

9- $\beta$-D-ribofuranosyl-9H-purin-6-amine<smiles>OCC(O)[C@@H](O)Cc1cncc([C@@H](O)[C@H](O)[C@H](O)CO)n1</smiles>

2,6-deoxyfructosazine

2-(D-arabino-tetrahydroxybutyl)-6(D-erithro-2,3,4-trihydroxybutyl)pyrazine<smiles>OC[C@H](O)[C@H](O)c1cnc(C[C@H](O)[C@H](O)CO)cn1</smiles>

2,5-deoxyfructosazine

2-(D-arabino-tetrahydroxybutyl)-5-

(D-erithro-2,3,4-trihydroxybutyl)pyrazine
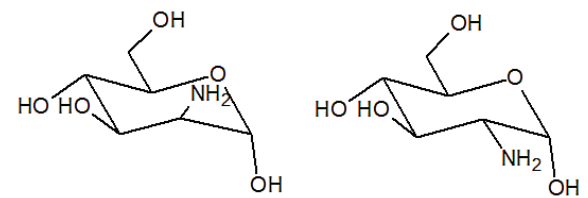

mannosamine 2-amino-2-deoxymannose glucosamine

2-amino-2-deoxyglucose

Figure 1. Chemical formulas for the compounds analyzed in this study.<smiles>CC(C)N[C@H](C)COCC(=O)C(O)C(O)C(O)CO</smiles><smiles></smiles>

Figure 2. Reaction of fructose (in open chain form) with ammonia to form 2,5-DF.

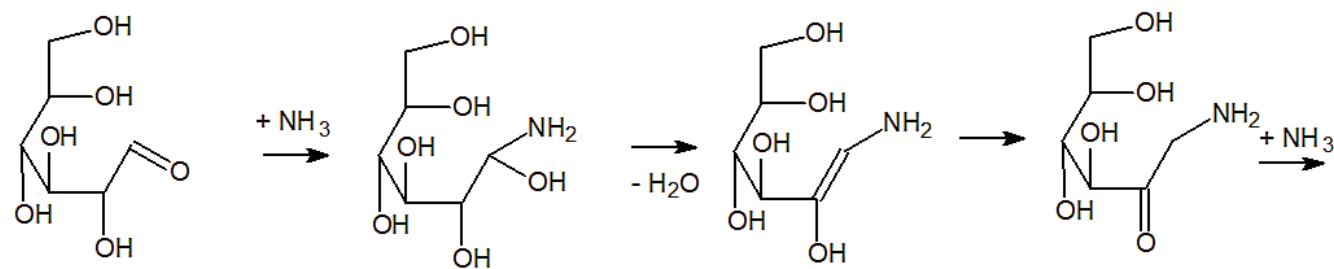

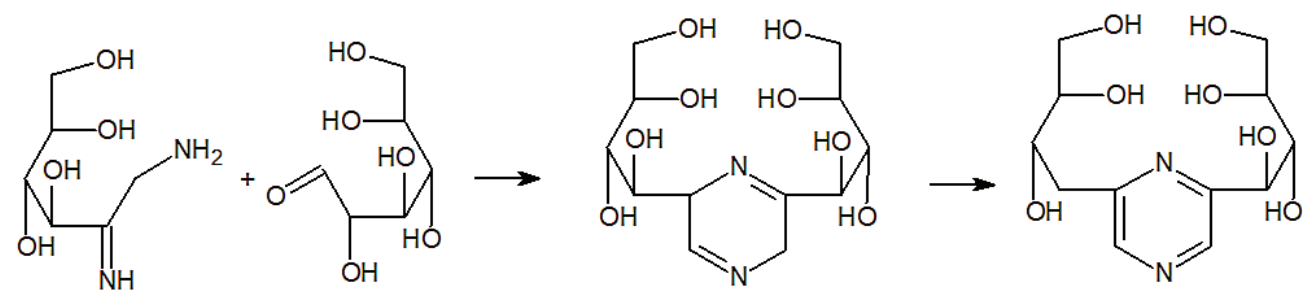

Figure 3. Reaction of glucose (in open chain form) with ammonia to form 2,6-DF. 
Table 1. Some tandem mass spectrometry MS/MS conditions used in this analysis.

\begin{tabular}{l|c|c|c|c|c}
\hline Compound & Transition from $\mathrm{m} / \mathrm{z}$ & Transition to $\mathrm{m} / \mathrm{z}$ & $\begin{array}{c}\text { Retention time } \\
(\mathrm{min})\end{array}$ & $\begin{array}{c}\text { Declustering } \\
\text { potential }(\mathrm{V})\end{array}$ & $\begin{array}{c}\text { Collision energy } \\
(\mathrm{eV})\end{array}$ \\
\hline DHP (I.S.) & 113 & 85 & 4.98 & 200 & 26 \\
Adenosine & 268.3 & 136.2 & 5.86 & 60 & 24 \\
2,6-DF & 305 & 227.3 & 8.16 & 60 & 26 \\
2,5-DF & 305 & 227.3 & 8.51 & 60 & 26 \\
Mannosamine & 180 & 162.2 & 10.42 & 60 & 13 \\
Glucosamine & 180 & 162.2 & 11.45 & 60 & 13 \\
\hline
\end{tabular}

\section{EXPERIMENTAL}

\section{Reagents and solvents}

Adenosine, mannosamine $\mathrm{HCl}$, glucosamine, $\mathrm{HCl}$ and 2,5dihydroxypyrazine standards as well as glucose, fructose and diammonium phosphate were obtained from Aldrich (Sigma-Aldrich, St.Louis, MO, 63168, USA). Acetonitrile was obtained from Fisher (Fisher-Scientific, Suwanee, GA 30024, USA). 2,5-DF and 2,6-DF are commercially available, but they were synthesized in this study using a reaction between fructose or glucose, respectively, and diammonium phosphate. For this purpose, $1.8 \mathrm{~g}$ reducing sugar (glucose or fructose) and $1.32 \mathrm{~g}\left(\mathrm{NH}_{4}\right)_{2} \mathrm{HPO}_{4}$ were each dissolved in $20 \mathrm{~mL}$ water. The solutions were mixed together in a round bottom flask adapted with an ascending condenser. The solutions were boiled for about 3 hours and the solution turned to a yellowish-brown color. The ascending condenser was replaced to a descending one which was also connected to vacuum (around $-50 \mathrm{~mm} \mathrm{Hg}$ ) and the reaction mixture was heated at a temperature not exceeding $90{ }^{\circ} \mathrm{C}$ until complete elimination of water. The solid dark brown residue was extracted three times with about $10 \mathrm{~mL}$ of boiling ethanol. In a few hours and upon cooling, 2,5-DF crystallized from the combined ethanol solutions if fructose was the initial reducing sugar. 2,6-DF was formed if glucose was the reducing sugar. The purity of the product was verified by HPLC using the same separation further discussed for the analysis of samples, but using UV detection at $276 \mathrm{~nm}$. From the peak areas in the chromatograms and assuming the same response factor for the two isomers, it was found that the 2,5-isomer was present at a level of about $5 \%$ in the 2,6-isomer, and even a lower level of 2,6-isomer was present in the 2,5-isomer. The two LC chromatograms presented in merge format of synthesized 2,6-DF (ret. time $8.16 \mathrm{~min}$ ) and of 2,5-DF (ret. time $8.51 \mathrm{~min}$ ) are given in Figure 4. The use of a refractive index (RI) detector in the HPLC separation was used to verify that no un-reacted sugar remained in the mixture.

\section{Sample analysis}

An amount of $100 \pm 0.1 \mathrm{mg}$ finely ground tobacco was weighed in a flask of at least $25 \mathrm{~mL}$ to start the analysis. To the sample was added $20 \mathrm{~mL}$ extracting solution consisting of $\mathrm{H}_{2} \mathrm{O} 90 \%+\mathrm{CH}_{3} \mathrm{OH} 10 \%$ with an internal standard. The internal standard (I.S.) was 2,5-dihydroxypyrazine (DHP) and its concentration in the extracting solution was $100 \mu \mathrm{g} / \mathrm{mL}$. This compound was selected since it is not present in tobacco, elutes close to the analytes, and has a good MS response. The extraction was performed on a VWR VX-2500 Multi-tube vortexer for $30 \mathrm{~min}$, at room temperature (VWR Scientific Inc., Bristol, PA 19007, USA). A few $\mathrm{mL}$ of the sample extract were filtered through a 0.45 $\mu \mathrm{m}$ PVDF filter (Whatman Inc., Florham Park, NJ 07932, USA). Only $0.2 \mathrm{~mL}$ of this solution was taken and diluted to $1 \mathrm{~mL}$ with a solution that also makes the mobile phase for the HPLC separation. This solution consisted of $78 \%$ $\mathrm{CH}_{3} \mathrm{CN}$ and $22 \% \mathrm{H}_{2} \mathrm{O}$ that also contained $0.1 \% \mathrm{HCOOH}$ and $0.143 \mathrm{~g} / \mathrm{L} \mathrm{CH}_{3} \mathrm{COONH}_{4}$. The amount of tobacco taken in this final solution was therefore equivalent with $1 \mathrm{mg} / \mathrm{mL}$. The extraction of tobacco first with $20 \mathrm{~mL}$ solution followed by further dilution was performed to have a tobacco sample of a size that allows a homogeneous sample, and to save some solvent. A volume of $2 \mu \mathrm{L}$ diluted extract was injected in a 1200 Agilent HPLC system (Agilent, Wilmington, DE 19808, USA). The system consisted of a degasser, a binary pump, and a WPALS autosampler and was equipped with a Luna $3 \mathrm{u}$ HILIC 200A column, $160 \times 4.6 \mathrm{~mm}$ from Phenomenex (Phenomenex, Torrance CA 90501, USA). The separation was performed in isocratic mode at a flow rate of $0.5 \mathrm{~mL} / \mathrm{min}$. The detector was a MS/MS system API 5000 from AB Sciex (AB Sciex, Foster City, CA 94404, USA). The acquisition was performed in scheduled multiple reaction monitoring (scheduled MRM) mode.

Table 2. Comparison between the results obtained using calibration and standard addition for a flue-cured tobacco sample.

\begin{tabular}{l|l|l|c|c|c}
\hline & $\begin{array}{c}\text { Adenosine } \\
(\mu \mathrm{g} / \mathrm{mL})\end{array}$ & $\begin{array}{c}2,6-\mathrm{DF} \\
(\mu \mathrm{g} / \mathrm{mL})\end{array}$ & $\begin{array}{c}2,5-\mathrm{DF} \\
(\mu \mathrm{g} / \mathrm{mL})\end{array}$ & $\begin{array}{c}\mathrm{Mannosamine} \mathrm{HCl} \\
(\mu \mathrm{g} / \mathrm{mL})\end{array}$ & $\begin{array}{c}\mathrm{Glucosamine} \mathrm{HCl} \\
(\mu \mathrm{g} / \mathrm{mL})\end{array}$ \\
\hline Result from calibration & 0.00148 & 0.10563 & 0.12465 & 0.27442 \\
Addition & 0.008 & 0.0 & 0.08 & 0.08 & 0.97701 \\
Expected result & 0.00948 & 0.10563 & 0.20465 & 0.35442 \\
Result from std. addition & 0.00926 & 0.10694 & 0.20311 & 0.35311 \\
Difference (\%) & -2.34 & 1.23 & -0.76 & -0.37 & 1.05701 \\
\hline
\end{tabular}




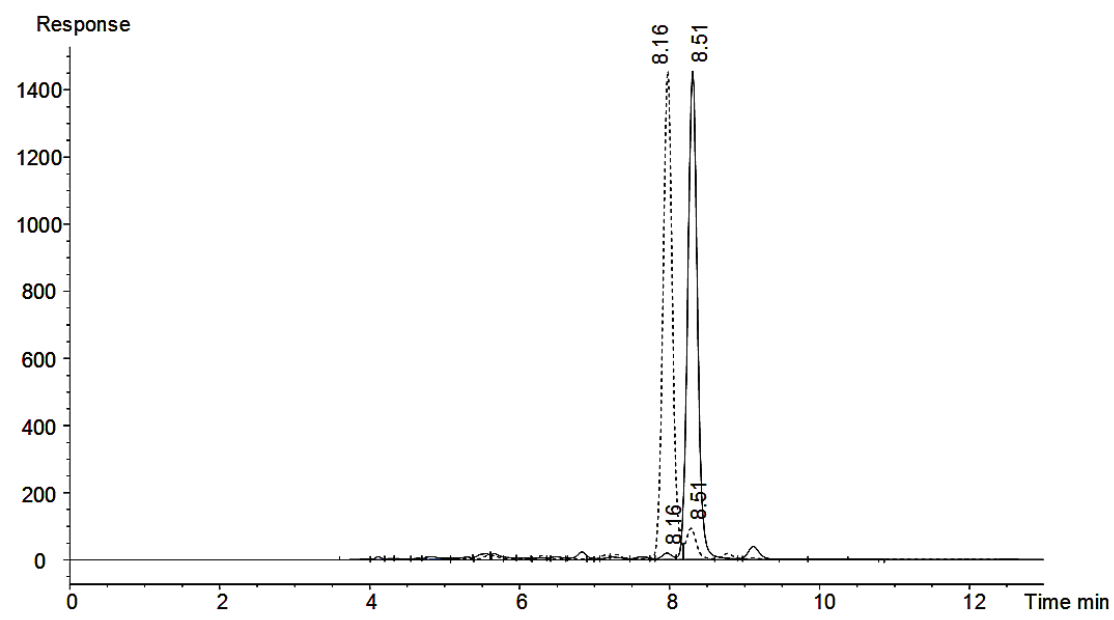

Figure 4. LC chromatograms of synthesized 2,6-DF (ret. time $8.16 \mathrm{~min}$ ) and of 2,5-DF (ret. time $8.51 \mathrm{~min}$ ) presented in merge format, as measured by UV detection at $276 \mathrm{~nm}$.

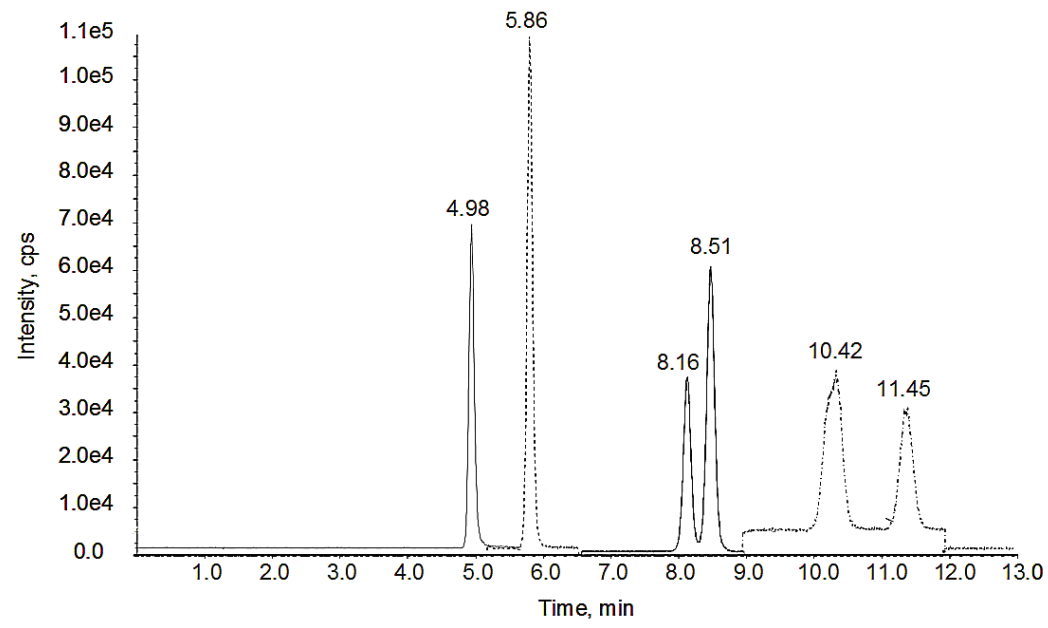

Figure 5. Typical LC/MS/MS chromatogram obtained for a standard solution containing $2.0 \mu \mathrm{g} / \mathrm{mL}$ I.S., $0.025 \mu \mathrm{g} / \mathrm{mL}$ adenosine, and $0.25 \mu \mathrm{g} / \mathrm{mL}$ of 2,6-DF, 2,5-DF, mannosamine $\mathrm{HCl}$ and glucosamine $\mathrm{HCl}$ (retention times related with the name of the compound given in Table 1).

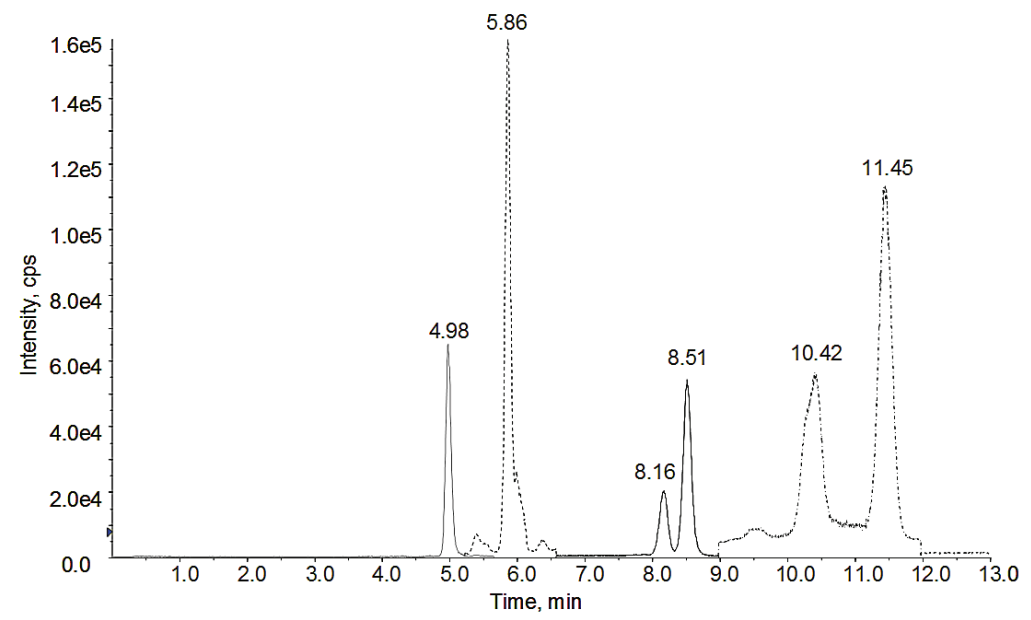

Figure 6. Typical LC/MS/MS chromatogram obtained for a tobacco sample from 3R4F Kentucky reference cigarette (retention times related with the name of the compound given in Table 1). 
Table 3. Results of five measurements of a flue-cured tobacco sample.

\begin{tabular}{|c|c|c|c|c|c|}
\hline Replicate & $\begin{array}{c}\text { Adenosine } \\
(\mu \mathrm{g} / \mathrm{g})\end{array}$ & $\begin{array}{r}2,6-D F \\
(\mu g / g)\end{array}$ & $\begin{array}{c}2,5-D F \\
(\mu g / g)\end{array}$ & $\begin{array}{c}\text { Mannosamine } \\
\mathrm{HCl}(\mu \mathrm{g} / \mathrm{g})\end{array}$ & $\begin{array}{c}\text { Glucosamine } \\
\mathrm{HCl}(\mu \mathrm{g} / \mathrm{g})\end{array}$ \\
\hline 1 & 0.69 & 54.08 & 62.88 & 135.68 & 468.43 \\
\hline 2 & 0.79 & 53.55 & 61.78 & 138.74 & 508.59 \\
\hline 3 & 0.75 & 54.95 & 57.12 & 136.60 & 498.56 \\
\hline 4 & 0.71 & 58.84 & 61.50 & 134.64 & 463.18 \\
\hline 5 & 0.64 & 59.21 & 58.43 & 130.42 & 484.23 \\
\hline Average & 0.72 & 56.12 & 60.34 & 135.22 & 484.60 \\
\hline RSD (\%) & 6.69 & 4.30 & 3.62 & 2.03 & 3.56 \\
\hline
\end{tabular}

Some of the conditions used for the MS/MS system are shown in Table 1. Other conditions for the MS/MS included source temperature $700{ }^{\circ} \mathrm{C}$, collision gas $10 \mathrm{~mL} / \mathrm{min}$, curtain gas $14 \mathrm{~mL} / \mathrm{min}$, ion source gas [1] $45 \mathrm{~mL} / \mathrm{min}$, ion source gas [2] $55 \mathrm{~mL} / \mathrm{min}$, entrance potential $10 \mathrm{eV}$, collision cell exit potential $10 \mathrm{eV}$. Under these conditions, a typical chromatogram for a solution of standards containing $0.025 \mu \mathrm{g} / \mathrm{mL}$ adenosine, and $0.25 \mu \mathrm{g} / \mathrm{mL}$ of 2,6-DF, 2,5-DF, mannosamine $\mathrm{HCl}$ and glucosamine $\mathrm{HCl}$ is shown in Figure 5 (the compounds identification can be obtained from the associated retention

Table 4. List of analyzed samples.

\begin{tabular}{|c|c|c|}
\hline Sample & Acronym & Description \\
\hline 1 & $\mathrm{FC} \operatorname{low}(\mathrm{A})$ & Lower stalk (lug) flue-cured A \\
\hline 2 & FC up (A) & $\begin{array}{l}\text { Upper stalk (leaf \& some tips) } \\
\text { flue-cured A }\end{array}$ \\
\hline 3 & FC low (B) & Lower stalk (lug) flue-cured B \\
\hline 4 & FC up (B) & $\begin{array}{l}\text { Upper stalk (leaf \& some tips) } \\
\text { flue-cured B }\end{array}$ \\
\hline 5 & FC low off & $\begin{array}{l}\text { Off-shore lower stalk (lugs \& } \\
\text { primings) flue-cured }\end{array}$ \\
\hline 6 & FC up off & $\begin{array}{l}\text { Off-shore upper stalk (leaf \& tips) } \\
\text { flue-cured }\end{array}$ \\
\hline 7 & Bur. low $(A)$ & $\begin{array}{l}\text { Lower stalk (flyings \& cutters) } \\
\text { burley A }\end{array}$ \\
\hline 8 & Bur. up (A) & Upper stalk (leaf) burley A \\
\hline 9 & Bur. low (B) & $\begin{array}{l}\text { Lower stalk (flyings \& cutters) } \\
\text { burley B }\end{array}$ \\
\hline 10 & Bur. up (B) & Upper stalk (leaf) burley B \\
\hline 11 & Bur. low off & $\begin{array}{l}\text { Off-shore lower stalk (flyings \& } \\
\text { cutters) burley }\end{array}$ \\
\hline 12 & Bur. up off & $\begin{array}{l}\text { Off-shore upper stalk (leaf) } \\
\text { burley }\end{array}$ \\
\hline 13 & Samsun & $\begin{array}{l}\text { Middle to upper stalk, Samsun } \\
\text { Oriental }\end{array}$ \\
\hline 14 & Izmir & $\begin{array}{l}\text { Middle to upper stalk, Izmir } \\
\text { Oriental }\end{array}$ \\
\hline 15 & Camel & Camel Blue \\
\hline 16 & M. Red old & $\begin{array}{l}\text { Old Marlboro Red ( } 2 \text { years } \\
\text { sample) }\end{array}$ \\
\hline 17 & Galpao green & Galpao green tobacco \\
\hline 18 & FC green & Flue-cured green tobacco \\
\hline 19 & Newport & Newport \\
\hline 20 & 2R4F & 2R4F (Kentucky reference) \\
\hline 21 & M. Red & Marlboro Red \\
\hline 22 & 1R4F & 1R5F (Kentucky reference) \\
\hline 23 & 3R4F & 3R4F (Kentucky reference) \\
\hline 24 & 1R4F & 1R4F (Kentucky reference) \\
\hline
\end{tabular}

time shown in Table 1).

The quantitation for each analyte was obtained using calibration with six standard concentrations and using linear equations of the form:

Conc $_{\mathrm{i}}(\mu \mathrm{g} / \mathrm{mL})=\mathrm{A}_{\mathrm{i}}\left(\right.$ Analyte $_{\mathrm{i}}$ Peak Area/I.S. Peak Area $)$

(where different $\mathrm{A}_{\mathrm{i}}$ values were obtained for each analyte). The standards had a concentration between $0.00125 \mu \mathrm{g} / \mathrm{mL}$ and $0.4 \mu \mathrm{g} / \mathrm{mL}$ for adenosine, and between $0.025 \mu \mathrm{g} / \mathrm{mL}$ and $4.0 \mu \mathrm{g} / \mathrm{mL}$ for the other analytes. The $\mathrm{R}^{2}$ values for the calibration lines were between 0.9968 (for adenosine) and 0.9994 (for glucosamine). This indicated excellent linearity in a wide range of concentrations.

\section{Validation of the analytical procedure}

Several steps were taken in order to provide information regarding the selectivity, precision, repeatability, limit of detection and quantitation, and recovery of the proposed analytical procedure (33). The linearity in a specified range of concentrations was already indicated previously. The selectivity of the separation was determined using standard addition on a lower stalk (lug) flue-cured tobacco sample. The analytes in the sample were measured using the previously established calibration, and then in $9.8 \mathrm{~mL}$ sample was added $0.2 \mathrm{~mL}$ solution containing $0.4 \mu \mathrm{g} / \mathrm{mL}$ adenosine and $4 \mu \mathrm{g} / \mathrm{mL}$ 2,5-DF, mannosamine and glucosamine, respectively. The results were calculated by extrapolation to zero intercept and are shown in Table 2. As seen from this table, the agreement between the results obtained using the calibration and those using standard addition were very good.

This result indicates that no interference is present in the separation. Based on the results obtained using the standard addition procedure for analysis the method described in this study was also considered to be accurate. However, no results in the peer reviewed literature were available for comparison and accuracy assessment.

The precision of the method was estimated by analyzing the same sample 5 times. The analyzed sample was that of a lower stalk (lug) flue-cured tobacco, and the relative standard deviations (RSD\%) for the results are given in Table 3. As seen from this table, the RSD $\%$ for adenosine is around $6.7 \%$, and for the other analytes is below $5 \%$. The repeatability of the method was verified over a period of one month. The repeated injection of the standard containing $0.025 \mu \mathrm{g} / \mathrm{mL}$ adenosine, and $0.25 \mu \mathrm{g} / \mathrm{mL}$ of $2,6-$ $\mathrm{DF}, 2,5-\mathrm{DF}$, mannosamine $\mathrm{HCl}$ and glucosamine $\mathrm{HCl}$ 
Table 5. Results (average of duplicates) for the analyzed samples expressed in $\mathrm{mg} / \mathrm{g}$ tobacco (as is).

\begin{tabular}{|c|c|c|c|c|c|c|}
\hline Sample \# & $\begin{array}{c}\text { Tobacco type } \\
\text { (acronym) }\end{array}$ & $\begin{array}{c}\text { Adenosine } \\
(\mu \mathrm{g} / \mathrm{g})\end{array}$ & $\begin{array}{r}2,6-D F \\
(\mu \mathrm{g} / \mathrm{g})\end{array}$ & $\begin{array}{r}2,5-D F \\
(\mu \mathrm{g} / \mathrm{g})\end{array}$ & $\begin{array}{c}\text { Mannosamine, } \\
\text { free }(\mu \mathrm{g} / \mathrm{g})\end{array}$ & $\begin{array}{c}\text { Glucosamine, } \\
\text { free }(\mu \mathrm{g} / \mathrm{g})\end{array}$ \\
\hline 1 & FC low $(A)$ & 0.74 & 52.82 & 62.33 & 114.63 & 408.13 \\
\hline 2 & $\mathrm{FC}$ up $(\mathrm{A})$ & 1.10 & 45.70 & 54.81 & 112.52 & 459.64 \\
\hline 3 & FC low (B) & 2.90 & 41.87 & 54.64 & 90.26 & 332.25 \\
\hline 4 & FC up (B) & 1.06 & 34.09 & 39.74 & 87.46 & 354.40 \\
\hline 5 & FC low off & 2.05 & 86.12 & 97.37 & 88.74 & 570.88 \\
\hline 6 & FC up off & 3.55 & 87.23 & 87.86 & 60.33 & 398.73 \\
\hline 7 & Bur. low $(A)$ & 0.35 & 12.64 & 36.34 & 30.50 & 121.64 \\
\hline 8 & Bur. up (A) & 0.43 & 27.60 & 79.53 & 52.59 & 207.36 \\
\hline 9 & Bur. low (B) & 0.71 & 16.13 & 53.54 & 25.33 & 133.95 \\
\hline 10 & Bur. up (B) & 0.47 & 10.91 & 40.15 & 16.10 & 67.50 \\
\hline 11 & Bur. low off & 1.32 & 14.12 & 56.24 & 24.02 & 128.75 \\
\hline 12 & Bur. up off & 1.28 & 31.82 & 108.26 & 43.57 & 215.76 \\
\hline 13 & Samsun & 0.75 & 209.90 & 324.64 & 298.60 & 1185.77 \\
\hline 14 & Izmir & 2.08 & 36.97 & 35.10 & 59.79 & 255.03 \\
\hline 15 & Camel & 11.31 & 140.99 & 227.51 & 308.22 & 992.83 \\
\hline 16 & M. Red old & 20.26 & 179.14 & 288.86 & 415.46 & 1401.82 \\
\hline 17 & Galpao green & 0.58 & 0.00 & 0.02 & 12.55 & 25.94 \\
\hline 18 & FC green & 0.66 & 0.00 & 0.22 & 34.85 & 97.69 \\
\hline 19 & Newport & 13.71 & 225.24 & 355.05 & 293.07 & 1093.27 \\
\hline 20 & $2 \mathrm{R} 4 \mathrm{~F}$ & 8.33 & 117.58 & 174.74 & 259.17 & 882.07 \\
\hline 21 & M. Red & 16.69 & 167.22 & 286.32 & 304.69 & 1008.97 \\
\hline 22 & 1R4F & 10.46 & 424.46 & 608.49 & 404.27 & 1885.75 \\
\hline 23 & $3 \mathrm{R} 4 \mathrm{~F}$ & 15.01 & 78.67 & 121.04 & 214.01 & 673.18 \\
\hline 24 & 1R4F & 14.80 & 303.17 & 342.91 & 256.96 & 1388.85 \\
\hline
\end{tabular}

showed less than $8 \%$ variability for a number of 15 injections for all five analytes. The sensitivity of the method was estimated based on the signal to noise $(\mathrm{S} / \mathrm{N})$ values. For the lowest standard $(0.00125 \mu \mathrm{g} / \mathrm{mL}$ adenosine, and $0.025 \mu \mathrm{g} / \mathrm{mL}$ of 2,6-DF, 2,5-DF, mannosamine $\mathrm{HCl}$ and glucosamine $\mathrm{HCl}$ ) the values were $\mathrm{S} / \mathrm{N}=30.4$ for adenosine, $\mathrm{S} / \mathrm{N}=22.8$ for $2,6-\mathrm{DF}, \mathrm{S} / \mathrm{N}=38.2$ for $2,5-\mathrm{DF}$, $\mathrm{S} / \mathrm{N}=12.4$ for mannosamine and $\mathrm{S} / \mathrm{N}=8.5$ for glucosamine. These values indicated a very good sensitivity of the method.

Except for glucosamine with a $\mathrm{S} / \mathrm{N}$ slightly below 10 , the values for the concentrations of the lowest standard were well suited for quantitation. However, the lowest standard for glucosamine was kept in the calibration curve since it did not affect the linearity. Since, except for the sample extraction, no sample preparation was performed in the method described in this study, the recovery was evaluated only from the point of view of the optimum solvent used for sample extraction. All analytes being readily soluble in water, this was considered the ideal solvent for extraction. However, water also dissolves some polymeric materials from tobacco, and these polymers may affect in time the chromatographic column. For this reason, a solution 90\% water with $10 \%$ methanol was selected as solvent. The comparison of the results obtained by using the two solvents showed no significant difference in the analyte extraction.

\section{RESULTS AND DISCUSSION}

A number of 24 tobacco samples was analyzed in duplicate using the procedure previously described. A typical LC chromatogram obtained for tobacco from a 3R4F Kentucky reference cigarette is shown in Figure 6 (retention times from Table 1 indicate the nature of compounds).

The analyzed samples consisted of a number of single grade tobaccos, two green tobaccos (dried in air) and a number of tobaccos from commercial and Kentucky reference cigarettes. The list of the analyzed samples with a short description of the material is given in Table 4 . The results of analytes content (on a "as is basis") is given in Table 5 (free base mannosamine and glucosamine are reported). All the samples were analyzed in duplicate. The relative standard deviations ( $\mathrm{RSD}^{\mathrm{o}} \mathrm{\text {) }}$ ) were typically around $5 \%$ or lower for all samples and all the analytes. Only a few results for adenosine showed $\mathrm{RSD} \%$ values between $5 \%$ and $8 \%$. Although obtained from only two replicates which provides a limited level of confidence, the low values of RSD\% for all samples are an additional indication of the good precision of the analysis.

A large range of levels of the analytes was noticed among samples. Except for an oriental tobacco sample (Sample 13) most analytes were found in general at higher levels in cigarette tobaccos compared to single grade tobaccos. The 


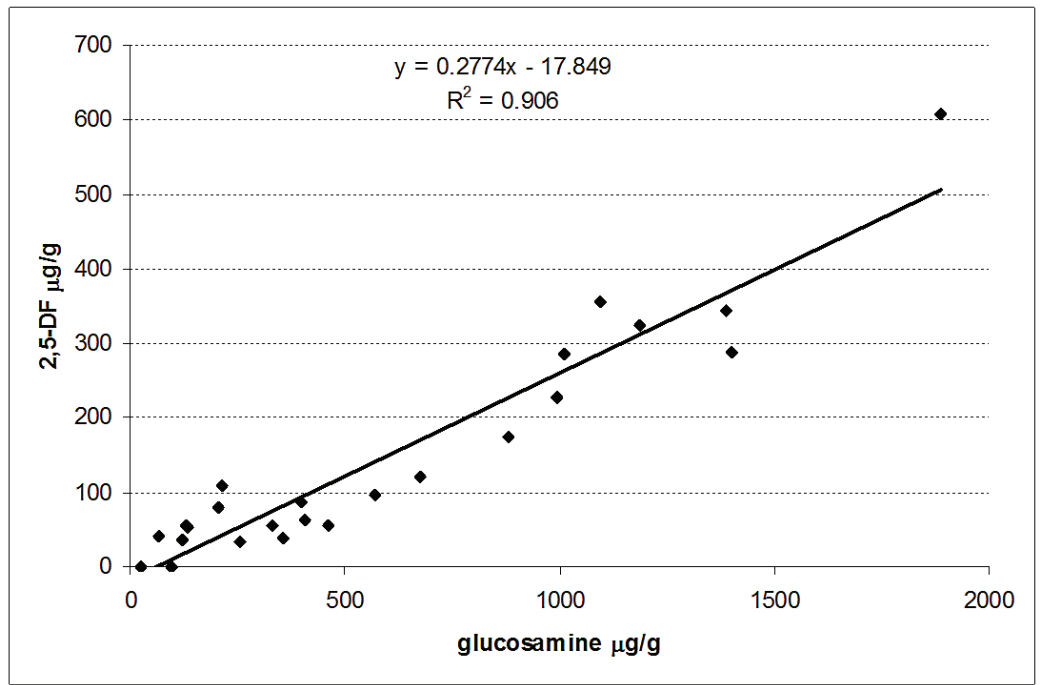

Figure 7. Linear correlation between the levels of glucosamine and that of 2,5-DF in the analyzed samples.<smiles>CC(C)OCC(=O)C(O)C(O)C(O)CO</smiles><smiles>NC(C=O)C(O)C(O)C(O)CO</smiles><smiles>OCC1CC(O)C2ONC1C(O)O2</smiles>

glucosamine mannosamine

Figure 8. Reaction of fructose (in open chain form) with ammonia to form glucosamine and mannosamine.

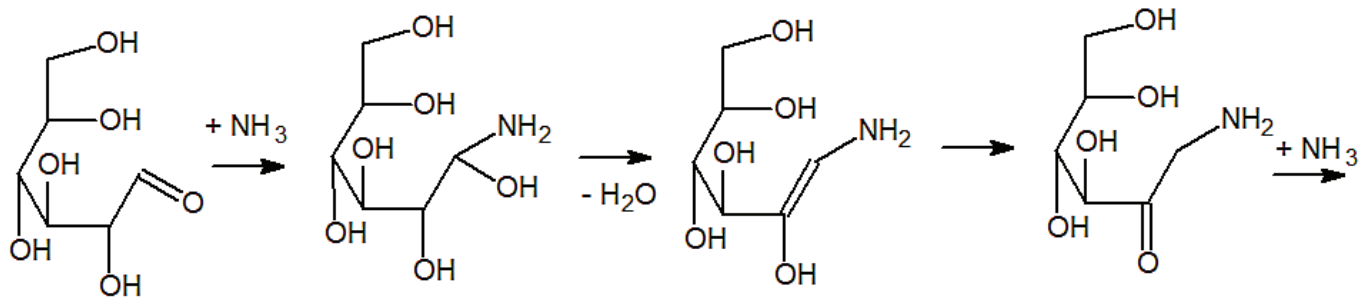

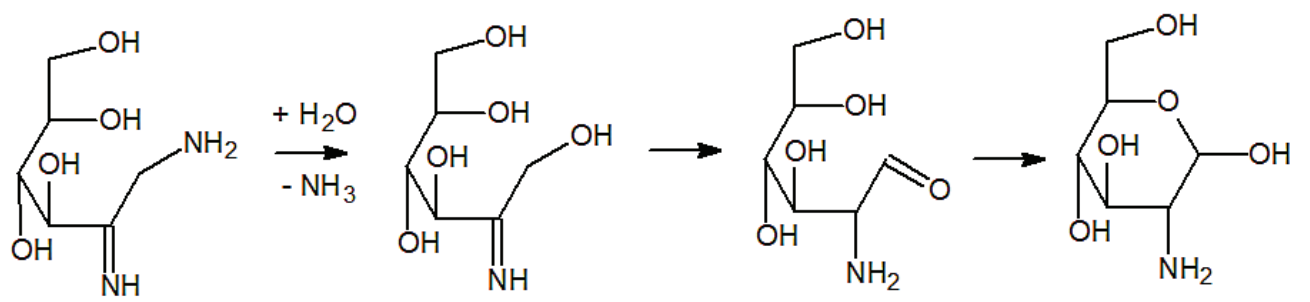

Figure 9. Reaction of glucose (in open chain form) with ammonia to form glucosamine (mannosamine can be formed by the same mechanism). 
green tobaccos were very low in all nitrogenous compounds analyzed in this study.

The levels of 2,5-DF and those of 2,6-DF correlate well, as expected. The linear correlation of their levels in the analyzed samples showed a $\mathrm{R}^{2}=0.9556$. As expected, adenosine levels do not correlate well either with the DFs or with the amino sugars (e.g. $\mathrm{R}^{2}=0.584$ for adenosine vs. glucosamine). Glucosamine and mannosamine also showed a good linear correlation, with a $\mathrm{R}^{2}=0.9198$. Not expected was that the correlation between the DFs and amino sugars levels was also very good. For example, glucosamine and 2,5-DF levels showed a linear correlation with $\mathrm{R}^{2}=0.906$. The graph of this correlation is shown in Figure 7.

This good correlation may indicate that the source of glucosamine in tobacco may be related to a source similar to that responsible for producing DFs, in addition to a potential synthesis from fructose 6-phosphate and glutamine (8). One such path is the reaction of a reducing sugar and ammonia. The reaction starting with an open cycle form of fructose for the formation of 2-amino-2deoxy glucose and of 2-amino-2-deoxy mannose may take place as shown in Figure 8. This reaction can explain both the good correlation in the levels of glucosamine and mannosamine, as well as the correlation between the DFs and the amino sugars.

The formation of glucosamine and mannosamine starting with glucose as the originating reducing sugar, may also take place following reactions as shown in Figure 9 for glucosamine (mannosamine is formed by the same reaction). Other reaction paths are also possible for the formation of amino sugars from reducing sugars and ammonia.

\section{CONCLUSIONS}

A new LC/MS/MS technique using a HILIC column for separation was developed and validated for the analysis of adenosine, deoxyfructosazines, mannosamine and glucosamine in tobacco. The method is simple, very sensitive and with excellent repeatability. A number of tobacco samples containing single grades tobaccos, two green tobaccos and a number of tobaccos from commercial and Kentucky reference cigarettes were analyzed. The $\mathrm{RSD} \%$ for the data were typically around $5 \%$ or lower for all samples and all the analyes. Only a few results for adenosine showed RSD $\%$ values between 5\% and $8 \%$.

A large range of levels of the analytes was noticed among the sample. Except for an oriental tobacco sample most analytes were found in general at higher levels in cigarette tobaccos compared to single grade tobaccos. The green tobaccos were very low in all nitrogenous compounds analyzed in this study.

The study also indicated that the levels of DFs and that of the amino sugars in tobacco show a very good correlation. This correlation can be explained by the presence of the same source of the two classes of compounds, namely the reaction of (reducing) sugars and ammonia. The good correlation between glucosamine and mannosamine can also be explained by the formation of the two compounds from fructose.

\section{REFERENCES}

1. Florin, I., L. Rutberg, M. Curvall, and C.R. Enzell: Screening of tobacco smoke constituents for mutagenicity using the Ames' test; Toxicol. 15 (1980) 219-232.

2. Curvall, M., C.R. Enzell, T. Jansson, B. Pettersson, and M. Thelestam: Evaluation of the biological activity of cigarette-smoke condensate fractions using six in vitro short-term tests; J. Toxicol. Environmental Health 14 (1984) 163-180

3. Mizusaki, S., H. Okamoto, A. Akiyama, and Y. Fukuhara: Relation between chemical consitutents of tobacco and mutagenic activity of cigarette smoke condensate; Mutat. Res. 48 (1977) 319-326.

4. Mizusaki, S., T. Takashima, and K. Tomaru: Factors affecting mutagenic activity of cigarette smoke condensate in Salmonella typhimurium TA 1538; Mutation Res. 48 (1977) 29-36.

5. Moldoveanu, S.C.: Analysis of Protein Amino Acids in Tobacco using Microwave Digestion of Plant Material; Beitr. Tabakforsch. Int. 21 (2005) 451-465.

6. Moldoveanu, S. C.: Analytical Pyrolysis of Natural Organic Polymers, Elsevier, Amsterdam, 1998, pp. 355-370.

7. Roseman, S.: Reflections on glycobiology; J. Biol. Chem. 276 (2001) 41527-41542.

8. Ghosh S., H.J. Blumenthal, E. Davidson, and S. Roseman: Glucosamine metabolism. V. Enzymatic synthesis of glucosamine 6-phosphate; J. Biol. Chem. 235 (1960) 1265.

9. Yoshioka, M. and Z. Tamura: Fluorimetric determination of adenine and adenosine and its nucleotides by high-performance liquid chromatography; J. Chromatogr. A 123 (1976) 220-224.

10. Zeng, H-F., C-H. Hung, J-Y.Wang, C-H.Chou, and H.$\mathrm{P}$. Hung: Simultaneous determination of adenosine and its metabolites by capillary electrophoresis as a rapid monitoring tool for 5'-nucleotidase activity; J. Chromatogr. A 1129 (2006) 149-152.

11. Tsuchida, H., M. Komoto, H. Kato, and M. Fujimaki: Formation of deoxyfructosazine and its 6-isomer on the browning reaction between glucose and ammonia in weak acidic medium; Agr. Biol. Chem. 37 (1973) 2571-2578.

12. Yang Li, Y., H. Zhou, Y. Liu, J. Deng, and C. Fu: Analysis of 2,6-deoxyfructosazine in browning reaction mixtures by GC/MS with silylation derivatization; Chin. J. Chromatogr., 24, PART 2, (2006) 212-214.

13. Mallu, U.R., K.H. Reddy, V. Bobbarala, and S. Penumajji: HPLC method development for glucosamine sulphate and diacerein formulation; J. Pharmacy Res. 3 (2010) 361-363.

14. Zhou, J., T. Waszkuc, and F. Mohammed: Determination of glucosamine in raw materials and dietary supplements containing glucosamine sulfate and/or glucosamine hydrochloride by HPLC with FMOC-Su derivatization: collaborative study; Available from (accessed April 2011): http://www.aoac.org/dietsupp6/ Dietary-Supplement-web-site/Fullcollab.htm.

15. Adebowale, A.O., D.S. Cox, Z. Liang, and N.D. Eddington: Analysis of glucosamine and chondroitin 
sulfate content in marketed products and the caco-2 permeability of chondroitin sulfate raw materials; JANA 3 (2000) 37-44.

16. Hagen, S. R.: High-performance liquid chromatographic quantitation of phenylthiocarbamyl muramic acid and glucosamine from bacterial cell wall; J. Chromatogr. A 632 (1993) 63-68.

17. Liang, Z., J. Leslie, A. Adebowale, M. Ashraf, and N.D. Eddington: Determination of the nutraceutical glucosamine hydrochloride in raw materials, dosage forms, and plasma using pre-column derivatization with ultraviolet HPLC; J. Pharm. Biomed. Anal. 20 (1999) 807-814.

18. Aghazadeh-Habashi, A., S. Sattari, F. Pasutto, and F. Jamali: High performance liquid chromatographic determination of glucosamine in rat plasma; J. Pharm. Pharmaceut. Sci. 5 (2002) 176-180.

19. Studelska, D.R., K. Giljum, L.M. McDowell, and L. Zhang: Quantification of glycosaminoglycans by reversed-phase HPLC separation of fluorescent isoindole derivatives; Glycobiology 16 (2006) 65-72.

20. El-Saharty, Y.S. and A.A. Bary: High-performance liquid chromatographic determination of neutraceuticals, glucosamine sulphate and chitosan, in raw materials and dosage forms; Anal. Chim. Acta 462 (2002) 125-131.

21. Hubert, C., S. Houari, F. Lecomte, V. Houbart, C. De Bleye, M. Fillet, G. Piel, E. Rozet, and P. Hubert: Development and validation of a sensitive solid phase extraction/hydrophilic interaction liquid chromatography/mass spectrometry method for the accurate determination of glucosamine in dog plasma; J. Chromatogr. A 1217 (2010) 3275-3281.

22. Zhong, S., D. Zhong, and X. Chen: Improved and simplified liquid chromatography/electrospray ionization mass spectrometry method for the analysis of underivatized glucosamine in human plasma; J. Chromatogr. B 854 (2007) 291-298.

23. Roda, A., L. Sabatini, A. Barbieri, M. Guardigli, M. Locatelli, FS. Violante, LC. Rovati, and S. Persiani: Development and validation of a sensitive HPLC-ESIMS/MS method for the direct determination of glucosamine in human plasma; J. Chromatogr. B. 844 (2006) 119-126.

24. Zhang, P., Z. Wang, M. Xie, W. Nie, and L. Huang: Detection of carbohydrates using a pre-column derivatization reagent 1-(4-isopropyl) phenyl-3-methyl-5-pyrazolone by high-performance liquid chromatography coupled with electrospray ionization mass spectrometry; J. Chromatogr. B 878 (2010) 1135-1144.

25. Miyamoto, I. and S. Nagase: A simple method for the determination of glucosamine and galactosamine using cellulose acetate electrophoresis; Anal. Biochem. 115 (1981) 308-310.

26. Skelley, A.M. and R.A. Mathies: Rapid on-column analysis of glucosamine and its mutarotation by microchip capillary electrophoresis; J. Chromatogr. A 1132 (2006) 304-309.

27. Esters, V., L. Angenot, V. Brandt, M. Frédérich, M. Tits, C. Van Nerum, J-N. Wauters, and P. Hubert: Validation of a High-performance thin-layer chromatography/densitometry method for the quantitative determination of glucosamine in a herbal dietary supplement; J. Chromatogr. A 1112 (2006) 156-164.

28. Kärkkäinen, J., A. Lehtonen, and T. Nikkari: Determination of glucosamine and galactosamine by gas chromatography; J. Chromatogr. A 20 (1965) 457-462.

29. Appuhn, A., R.G. Joergensen, M. Raubuch, E. Scheller, and B. Wilke: The automated determination of glucosamine, galactosamine, muramic acid, and mannosamine in soil and root hydrolysates by HPLC; J. Plant Nutrition Soil Sci. 167 (2004) 17-21.

30. Zhang, X. and W. Amelung: Gas chromatographic determination of muramic acid, glucosamine, mannosamine, and galactosamine in soils: Soil Biol. Biochem. 28 (1996) 1201-1206.

31. Kakehi, K., K. Maeda, M. Teramae, S. Honda, and T. Takai: Analysis of sialic acids by gas chromatography of the mannosamine derivatives released by the action of N-acetylneuraminate lyase; J. Chromatogr. B 272 (1983) 1-8.

32. Shen, X., M. Yang, and S.A. Tomellini: Indirect fluorescence detection of amino sugars with the use of copper complexes of tryptophan and its analogues following high-performance liquid chromatographic separation; J. Chromatogr. A 1072 (2005) 273-277.

33. Moldoveanu, S.C., V. David: Sample Preparation in Chromatography, Elsevier, Amsterdam 2002, pp. 107-108.

Corresponding author:

Serban C. Moldoveanu

R. J. Reynolds Tobacco Co.

Winston-Salem

NC 27105, USA

E-mail:MoldovS@RJRT.com 